A MHANOSCRIPT TREATISE ON THE CONNAGE BY JOHN PRYSE, 1553.

Mrattention was drapn to the existence of this treatise in the library of New College, Orford (MS. 317, iii), by a note in Wood's 'Athenae.' I desire to express my sense of the rery great kindness of the authorities of the college who allowed me the fullest facilities for examining it.

The author of the treatise is John Pryse, whom re may fairly, though not certainly, assume to be Sir John Price, ${ }^{1}$ or Ap Rice, of the Priory, Brecon, the well-known civilian and visitor of the monsateries. In the course of the manuscript he mentions that he hes written a larger trestise on the currency, but it has unfortanately not been preserved. This shorter work consists of an address to the queen, an exposition of general principles, a statement of the evils of debasement and of the condition of the coinage in 1553, and a careful consideration of the best means of reform. It is hoped to deal separately with the detailed information which Pryse gives in connexion with other eridence of the same kind, but his 'founda. tions,' as he calls them, are best set out by themselves. They may with adrantage be compared with the speculations on economic theory contained in the dialogue on "The Common Weal of this Realm of England' (1549, edited by Miss Lamond and Dr. Cunningham).

\title{
W. A. J. ARCEBOLD.
}

Things to be taken for sure grounds about the restitution of the coin :

First : that like as no prince can set price of any wares to endure for any time, no more can he bring to pass that his coin shall be better esteemed specially any long time, than the goodness of the metal that the coin is made of doth require, because every realm must hare traffic with other, and metals have their prices set certain, one above an other in their degrees through the whole world, as one portion of gold is worth twelve times as much silver, one of silver is worth one handred and forty parts of tin and quicksilver, and of brass two hundred and twenty parts, and of lead eight handred parts and of iron one thousand two hundred and eighty parts or therabout most commonly, bat as the finer of every sort of these is somewhat dearer than the rest, so are they all better chesp, where they be digged, and where they be plentiful than elsewhere. And albeit base coin of coarse metal hath for a season sometime been reputed as good as fine silver, that was like as a man that taketh a counterfeit grost as good as a true, or a counterfeit diamond for a true, till he know it, and then esteemeth it as it is worthy. And if a prince might value his money at his pleasure, then might he provide that there should never be dearth of snything in his realm, bat as the price of corn, or other thing doth rise, he might rise like rise the price of his money.

Then it must be confessed that money is the common measure of all things that are rendible and like as one metal is esteemed by an other as

I Seo an accoant of him in the Dietionary of Naticnal Biography. 
afore is declared, so are other things vendible esteemed and measured by the metal, that the money which is given for it is made of.

Also that the coin or print of the money is bat as a seal or a mark that should testify what quantity and goodness every piece should bear and contain, as some names of money, jet kept in use in the English tongue do declare as a pound of sterling money was also a pound in weight. . . .

This must be taken also for confessed that as the coin is abased the price of all things that are rendible must and do arise after the same portion that the coin is so abased, if it be more, more, if it be less, less. And that there is two ways of absing the coin one by mixture of base metal with fine, and to atter it as though it were all fine, which is the deceit that is impated to these alchemists. The other is by giving less weight of good metal in the coin, than the nature, name and credit of that coin doth require, which is much like as if the clerk of the market, world put the King's seal to a less bushel or to any other measure or weight, than that which was ased and allowed beforetime.

Also it must be confessed that these two last fants are now deprehended and known universally to be in our coin both baseness of metal in the mixed coin and less reight in the fine, than the name which it beareth doth require by one part in three.

And yet besides that, one other fault as great as any of them, that is lack of equivalence in the coin current, forasmuch as one testoon is better than another the fine new coin better than the base unirersally, and yet all at one estimate in the market, which inequality is cause of much robbing of the treasure of the realm, while the best money is ever picked, and carried over, and the Forst only left us. . . .

It must be therefore confessed for the causes aforesaid that therefore there is given for our coin now of any wares outward or infard, not after the name that our coin doth bear, but after the value of the metal that is in it (as in things bought beyond sea doth well appear) for as in ten shillings of our money now, there is bat two oz. of silver which was before in twenty groats sterling so ye heve bat so much ware for your ten shillings now, as you had for twenty sterling groats before. And though it be so well of wares bought beyond sea, as of men that esteem things rightly, get for most things bought within the resim, je pay more than after that rate, over that ye were wont to pay, when sterling was at ten grosts the oz: as if ye peruse and confer the old and new prices of a pig, goose, capon, chicken, and of all other victual for horse and man, ye shall soon perceive, which is by reason our people think our money yet worse than it is in deed. And so in more discredit with them than the right.value of it doth require which is long of the baseness of the said coin, which being depared, would take awry that discredit and bring all men to esteem the coin at the least ways at no less value than the stuff thereof did require. Also this can not be denied, but that it were better for all men to hare this coin, once called to his right name correspondent to his just value, though there were once some loss to be borne therein whereby men should be erer after assured that they should have no less therefor than the name thereof dath purport than as they be now to be daily and yearly deceived the third part in every piece or sum that they receive. ... 
PRICES $\triangle T$ WOODSTOCK IN 160 t.

Ir is generally assumed by the economic historian that with the decline of the gild system, with more rapid circalation of money, and with wider opportunities for the use of capital, prices gradually came to be fixed by competition rather than by custom or definite regulation, and that, with the exception of labour and of bread, this change was complete by the Tudor period. There is, horrever, a good deal of evidence to show that public control and regulation, acting through the central or through the local authority, to which power was delegated for the purpose, continued to be a common feature in some directions during Tudor and Stuart times, and covered a wider range than food, although this is the commodity of which, as might be expected, we hear most. Professor Ashley, in speaking of the sisteenth century, points to 'the general cessation of the attempt to assess victuals' as 'conclusive evidence of the diminishing vigour of municipal life; ' and elsewhere, when dealing with the loss by the gilds of power to fix the prices of wares, ${ }^{2}$ he implies that such prices were henceforth unregulated. From this view I find myself obliged to dissent, for it would be possible to show that in every one of the rictualling crafts, and in the case of some raw materials and some manufactured commodities, prices were frequently regulated during the sixteenth and seventeenth centuries by the state, which acted sometimes through the central, Bometimes through the local municipal authority. Of the general enforcement of such regulation it is difficult to speak with certainty. The presence or absence of indictments can be used as an argument in favour of effective action or the contrary, but there is a fair amount of evidence to show that the local authorities in many different places, in connexion with many different commodities, endeavoured to maintain such regulation as had been laid down either by the

1 Econs Eist. pt. ii p. 47.

- Ibid. p. 160. This loss of porrer Prolessor Ashley attributes to 19 सen. VII, c. 7. But the preamble to thet statute, in laying stress on the ' cnressonable ordinences, as well in prices of wages as other things,' definitely refers to 13 Ben. VI, c. 6. Bg this earlier wct the crafts there to make "none other ordinance of charge if it be not first discossed and approred for good and reasonable by the justices of the pesce and the govirnors of cities and torns, and beforo them entered of record.' This was enected 'to endure as long as it shall please... the king.' Thus the crafts as early as 1438 lost independent control over prices for time; the expiration of 15 Elen. VI, c. 6, and the evil results which follorred are stated as reasons for renewred legislation in 1504 . By 19 Hen. YII, c. 7, the crafts are, in general terms, forbidden to mate any ordinsnces withont the senction of the chencellor, treasurer, and some justices of either bench, or before the justices on cirenit. Bat there is nothing in the later statate which would seem to mark 's most significant departure ' on the part of parliament, for earlier legislation had already robbed the gilds of supreme control in the matter of prices, and the main difference betpeen the tro acts is one of detail, as to whether supervision shall be exercised by central or by local acthority. In neither case is there any suggestion that parliament inteaded to lesve individuals treedom in the matter. 
central or by the local authority, in any particular direction. In this matter of regalation there seems to be bat little change during the Tudor and early Staart period from the practice of an earlier time, of which, as of the later period, it would be difficult to prove that regulation of prices was universal, or that it was always rigidly enforced.

The following statements of prices as presented by the jurors of the royal borough of Woodstock in the 'Curia Assisarum' of 1604 is of some interest in this connerion, and indicates how minute were the details which came before such a court. ${ }^{3}$ Thus the price of a single or of a double bed, of a feather bed or a flock bed, by the night or by the week, is a matter upon which sworn information is given, and which apparently cannot be left for private settlement by individuals." Mr. Adolphus Ballard, torn clerk of Woodstock, to whom readers of this Review are indebted for the communication of the document, tells me that copies of thirteen assizes of bread and ale are to be found among the Woodstock records, but this is the only one of a more comprehensive character. The document is, indeed, incomplete as an assize, for no note is made fixing future rates, but it is not anreasonable to infer that in this, as in cases where bread and ale were dealt with in the same court, ${ }^{6}$ sworn information was given with a view to authoritative regulation ${ }^{7}$ by the mayor, who acted as clerk of the market." Regulation of this kind was still sufficiently common to warrant the suggestion that we probably have another case here. The desire to keep down unreasonable prices in the interests of travellers comes out in varions instances, and this may account for some of the elaborate details enumerated in the Woodstock document. Thus the maximum price of a meal was carefally fired at Norrich in 1569,9 and at a

- They were hardly less triviel than the fixing by statate of a maziona price for a nightcsp, 21 Hen. VIII, c. 9.

- The North Riding sessions frequently dealt with cases in the seventeenth century whon innkeopers bept ferrer beds than the court had stipolated to be necesanty for the practice of their calling. In 1581 the Mranchester Court Leet directed a jorg to search all ings, and to certity to the steward ' what beddinge they bave. . . also to viewe what rowmes and stablings they bave . . . and whether they have kept the assyse : . factum cat.- Harchester Count Leat Records, i. p. 219.

- Unless the words 'every men . . . to pay for his meele vjd.,' and 'the omner of the same horse to paye,' imply regulation.

- The assize of bread and ale for 1626, printed by Mr. Ballard in his Chronictes of Foodutack, p. 140, is a good instance. The prices of whent are quoted, end the mayor then proseded to set the assize.

- Such consaltation with persons possessing special knowledge was common belore change of price were made. In the case of labour, the jastices rere instructed by 5 Elix. c. \& to call together 'discrete and grare percons' and to confer with them respecting plenty or scarcity and 'other cireumstances necessary to be considered' before firing wages.

- Chrom of Woodstock, p. 68.

- Therees There bathe bene complajate made to Mr. Major and to the Justices of the greate excessjre charges $r$ Gentylmon Sarvingmen and other Travilors be at 
much later date in London. In 1639 we hear of measures taken by the central anthority, acting both directly and indirectly : of these it may not be out of place to make mention, as they bear on the general question as well as on the special charges of innholders. A proclamation published by the lord mayor in 1638 illustrates clearly what could still be done in London by anthoritative regulation. ${ }^{10}$ From it we learn that the lord mayor and aldermen were enjoined by the privy council to ' set such prices as they should conceine to be fit for all small Acates and other prouisions, and to set up the same in pablike Tables . . \& \& also should rary them from time to time as they should find just canse.' This the ciric authority did, 'streightly charging and commanding . . . that enery person do obey and keep as well the asid prices, as all other prices that shall from time to time hereafter be set and appointed by the said Lord Mayor for any proaision of Victnall whatsoeuer.' The rates of maximum prices which follow are less exhaustive than we should expect, and deal with all kinds of poultry and eggs; this is explained by the fact that the high price oi poultry is definitely mentioned as an intolerable grievance that required attention. The privy council are said

to have taken care to reforme many abuses . . . as the excessine number of Tavernes, and the extortions used in the immoderate prices of all sorts of proaisions in Ordinaries and Hosteleries; and finding that the said abuse hath appeared in nothing more than in the excessiue rates of Poultry of all sorts being so unreasonably enhaunsed by Poulterers and Higleors hare signified the command, \&c.

In the same year we find that the attorrey-general was instructed to study. the laws and statutes concerning prices of victuals and horsemeat, and to consult with the judges. This was done, a report was drawn up and presented to the Star Chamber; a decree was then drafted, in accordance with the recommendations made," which in the following month was confirmed by letters patent. ${ }^{12}$ Definite prices are laid down :

when they heve any occasion to resorte to this Cittio eswell for ther dyetts at ther ostes howses or at other victualing horises as for ther horses meate and gresse for ther hores Therfor this daje by the bole concente and advice of this borse yt yo ordeyned end agreid for the Reformacon therof that No Inkeper nor Victaler Drelling within this Cittie shall from this daje tyll the Feeste of the byrthe of our Lorde next comyng Taks any more mony for a dyarer or a Supper of any body then iijd., and to provyde for them porrage or Sew (?) with befe or Matton boyled and a stroke of Süme kynde of Roste and no more. And that from the seyde Feaste of the byrthe of the Lorde tgll Eater then next follonyng to take $v d$. for a mele and no more and the dyett to be as before js deciaryd saryog in Lente. And that no Intepar nor other $\mathrm{Y}^{\mathrm{t}}$ use to take horse to gresse within this Cittie from this Daje till the sayde Feaste of the brrthe of our Iorde next comgng shall take abore lijd. the daye and njght for a horse and yt he tarry bat a nyght then to take ijd. s night for a horse and no more. Coust Book 8 (1562-1569), under 7 Jane, 6 Eliz. p. 209.

10 Brit. Mrus. Harl. 1003, f. 48.

"Foedera, dix. 176.

12 Tbid. p. 179. 
We wish that Ordinaries in and about Iondon may be regulated to a convenient summ, not to exceed two shillings for a meal. . . . sir pence day \& night for Hay for a Horse, and for Oats six pence a peck Winchester mearure, is a competent rate to be taken by Innholders \& to take nothing for Litter. . . . for Horses which come to Inns in the day time we conceive it to be a reasonable rate for the Innekeeper to take a penny for a borse for his stable room only, the horse not being anbridled: if he be unbridled and have hay and go away the same day to take two pence the horse and no more.1:

These rates were made general for the whole kingdom, and ' $w$ here Grain and Hay are sold at lesser prices there the rates and prices shall be accordingly . . . until it shall be made to appear ... to the Justices of the Peace that because of the increase of prices in the parts adjoining greater rates are necessarily to be permitted.'

Of almost every article mentioned in the Woodstock document it woold be possible to quote instances of regulation during the Tudor and Stuart periods, scattered about in the statute book or in municipal records, but so far as I know there is no single list which is as fall as the following statement, drawn up with a view to regulation of prices by the local authority at Woodstock in 1604 .

Ellee A. McArthur.

Burgus nove Woodstock) Curio Assissanum dñi Regis clirici Mercstus burgi in Com Oxon

predicti ibidem tenta vicesimo die Angustii Anno regni dini ñi Jacobi Regis Anglie secundo et Scocie Tricesimo Octavo Annoque dñi 1604 coram ven ${ }^{l i}$ viro Willo Meatcalfe generoso maiore Burgi predicti.

\begin{tabular}{|c|c|c|}
\hline $\begin{array}{l}\text { Noïa Jũ } \\
\text { pro Dĩo Rege }\end{array}$ & $\begin{array}{l}\text { Johes Raunson } \\
\text { Rad Bradshewe } \\
\text { Willus Ball } \\
\text { Richsrd Wrighte } \\
\text { Michrell Nursse } \\
\text { Johes Lowe } \\
\text { Willus Edwards }\end{array}$ & 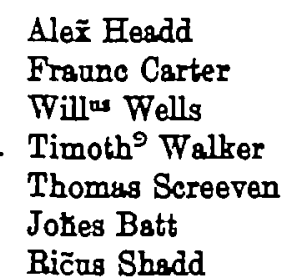 \\
\hline
\end{tabular}

Qui presentant super eorum sacramentum modo et forma sequente.

Inprimis a quarter of the beste wheate cleene \& sweete in the markett

Itm a quart second wheste in $y^{\bullet}$ mikett

It a gter third wheste in the markett

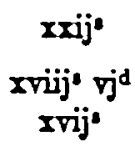

19 This is a considerable edrance on the price at Woodstock in 1604. Fynes Morjson, whose Itinorary was pablished in 1617, lags grest stress on the excellence and chenpness of English inns as compared with those of the continent. For eating ' at an ordinarie table together where they had great plentio of good meate, and especially of choice kirds of fish, each man paid no more than 6d. \& sometimes but 4d. a meale. . . One horses meste will come to trelve pence, or eighteen pence, the. night for Hay, Oates and Strew, and in Summer time commonly they pat the horses to grasse after the rate of thied pence each horse'-Itinerary, pt. iii. p. 61 . 
Itm a $\tilde{q} \ell$ best Mawlte cleene \& sweete in the markett

It a $\mathrm{q}^{\mathrm{t}}$ second Ma wlte in the Markett

it a $\tilde{q}$ Q beanes or pease in $y^{*}$ mkett

It 8 q ter beste ostes in the markett

It a busshell of the same ostes in eVye house

It a bilderkin of good Ale or dubble beere $w^{\text {th }}$ carriage

It a kilderkin single Ale or beere $w^{\text {th }}$ carriadge

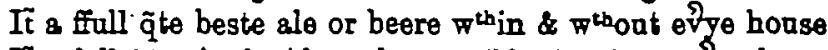

It a full qute single Ale or beere $w^{\text {th }}$ in \& $w^{\text {th }}$ out $\theta$ of

It a pownde of Butter sweete and newe in the markett

It Tenn Eggs the best in $y^{\bullet}$ mbett

It iiij of the same Eggs in evfye house

It a stone beste beefe at the Butcher's, weighinge viii lb

Iit a stone seconde beefe at the butcher's

IT. a:q̆ter beste Veale at the butcher's

It a q q' second Veale at the butcher's

If $a$ qit beste weather Mratton at the butchers

İ a $\tilde{q}$ t second Mutton at the botchers

If a fatt goose the beste in the mikett

It a fatt pygg the best in the mikett

It a lesne or second pigg in the mikett

It a coople of Caponetts the best in $y^{\bullet}$ mkett

If a coople second Caponetts in the marisett

It a coople of Chickens or Rabbetts the best in yo mikett

If a coople second Chickens or Rabbetts in the mkett

It a dozen pigions the beste in the mkett

It eṽye man beinge in companye gix or more togeather havinge to dinner or supper goodd bread and drinke Beefe \& Mratton boyled or rost Or els Veale boyled, pigg, beefe, or Veale rost, Or otherwise uppon the fisshe dayes havinge good bread and drink salt fishe or Salt Salmon Ling, egge \& butter, and so in default of one meate haringe another to pay for his meale

It a pownde of Tallowe candles made of wicke

It a fetherbedd for $j \mathrm{~ms} j$ night \& so to departe

Ii a fetherbedd with necessary apparrell thereunto for one ma alone by the weeke

It the like fetherbedd \& furniture for Two togeather by the reeke

Ii a matterice or fllockbedd for one or twoe together by the weeke

It iij house loves at the bakers êेye lofe weighinge xiiij ozs troie

It ij of the same loves in êेye house

It a C weighte of good sweete haye beinge crij" ${ }^{\text {th }}$ carriage

It efye bottle of haie weyinge ij"

It a load of Strawe for litter $w^{\text {th }}$ cariage

It haie \& litter day \& night for $j$ horse in êे $\theta$ Inn

It in êेe other house

It good grasse for one horsse day and nighte and so departe

Itm good grasse for one horsse alone by the weeke

ziij• iiijd

xij»

rij*

जं

siiijd

$\mathrm{iij}^{2} \mathrm{iiijd}^{d}$

Iviijd

jd

ok

ijd uo

$\mathrm{ij}^{\mathrm{d}}$

$j^{4}$

xiiijd

zijd

$\mathrm{xI}^{\mathrm{d}}$

Iviijd

ije

xrij

$x^{d}$

$x j^{d}$

$x^{d}$

$x j^{d d}$

$x^{d}$

viijd

$v^{d}$

$\mathbf{x}^{\mathrm{d}}$

vid

ijjd

$j^{d}$

$\nabla^{d}$

viji

iiijब

$j \mathrm{~d}$

jd

rijd

ob

iij" $j^{d}$

$\nabla^{d}$

iiijd

$\mathrm{ij}^{\mathrm{d}}$

viijd 
It. $\mathrm{fff}$ any horse abide in any pasture orer and above one day \& one night then the owner of the same horsse to paye after the rate of the whole weeke for so longe as he shall abide in the same pasture beinge as aforesaide

Itro a losde of Logg woodd $w^{\text {th }}$ cariage

Itm a $C$ good ffazgotits $w^{\text {th }}$ cariage

Itm ij of the same ffaggotts in eगेye house

Itm a loade of good brushe Bavens T $^{\text {th }}$ cariage

Itm a vacant or empty Chamber or Stable by $5^{\circ}$ weeke

Itm a $\mathrm{C}$ of good Oke borde beinge inch borde $\mathbf{w}^{\text {th }}$ cariage

Itm a $\mathrm{C}$ good Elme borde being inch borde $w^{\text {th }}$ cariage

Itm a Thousand Bricke $\boldsymbol{t}^{\text {th }}$ carisge

Itm \& $\tilde{q} t$ beste clarett Wine at the vintners

Itm a qut best Sacke at the Vintners

Itm a quter of Charcoles conteining viij busshells $\mathrm{w}^{\text {th }}$ cariage

viija

iiij" jid $^{d}$

iij" viijd

ijd

$\mathrm{ij}^{2} \mathrm{vj}^{\mathrm{d}}$

iiijd

iiijd

iije jid $^{d}$

$x^{d}$

$\mathrm{rij}^{\mathrm{d}}$

$x^{d}$

siiijd

STAR CHANCBER PROCEEDIRGS AGANNBT THE EARC OF SUFFOLK AND OTERES.

THE following account of the proceedings in the Star Chamber in 1619 against Thomas Howard, Earl of Suffolk, the lord treasurer, the countess of Suffolk, and Sir John Bingley, I have copied from a manuscript volume to which I have been allowed access by the kindness of Henry John Pye, Esq., of Clifton Hall, near Tamworth. The book appears to be a kind of commonplace book in which parious members of the Pye family entered from time to time extracts from books or pamphlets, copies of letters, and any other matters which seemed noteworthy in pablic affairs. Some of these entries are, I believe, in the handwriting of Sir Robert Pye of Faringford, who in July 1618 was made remembrancer of the exchequer and who died in 1662 . Others are entered by his son Robert, who married Anne, the daughter of John Hampden, and who sat in the parliaments of 1654 and 1657 as member for Berkshire. He died in 1701. The commencement of the subjoined account appears to be in the hindwriting of the elder Sir Robert and is continued and concluded by a clerk or secretary.

\section{A. P. Percepal Kegp.}

In Camer Stellaț coram Concilio ibidem decimo tertio die. Norembris Anno decimo Septimo Jacobi Regis. Presentibus Dño Cač. Angt Archiep̃o Cant, Duce Lenox, Ep̃o London, Marchäe Hamilton, Ep̃o Winton, Coñte Pembroke, Dño Mountagu Capt. Jastic. de Banco Regis, Dño Digby, Dĩo Hobart Capt. Justic. de Comãn Banco, Thom. Edmonds Mil., Rotto Naunton Mil. Secret Rs., Geo. Calvert Mfil, Secret Rs., Fule. Grevill Mil. Canc. Scciii, Edw. Cooke Mil.

Ters day as also ten other sitting dayes this Terme were wholly spent in the solemne and deliberate hearing, discussing and sentencing of the 